\title{
ON GRAPHICFEATURES IN SPELLING CODIFICATION OF RELIGIOUS LEXICON IN THE CHURCH DICTIONARY BY P.A. ALEKSEEV
}

\author{
Sergey V. Feliksov \\ Saint Tikhon's Orthodox University, Moscow, Russia
}

\begin{abstract}
The research is held in the field of Russian orthographic norm studies, it deals with the issue of formation and dynamic evolution of the orthography in the history of the Russian language, in particular, it is aimed at observing codification and stabilization in spelling of the words that are referred to the confessional and terminological system of orthodox dogma, at distinguishing formation of spelling standards in religious style.

The article presents some results of the linguatextological analysis of two editions of The Church Dictionary compelled by archpriest P.A. Alekseev in 1773-1779 and 1794 accordingly. The Church Dictionary is the first one in the history of Russian lexicography practice that collected and defined meanings for the words from religious sphere. Deep consideration of the data under study resulted in the following conclusion on codification features: the author stated morphological, traditional and phonemic characteristics, highlighted coordination between principles of spelling codification in The Church Dictionary and the previous works on lexicography and grammar. The cases of alternative word spelling were revealed, and their variability is explained as being associated with the graphic and orthographic spelling types (graphic and phono-morphological alternations in particular), as well as morphemic types with purely morphemic norms and morphophonemic alterations, and finally with the etymologic and word-forming types. The author offered his reasoning on word spelling variability fixed by P.A. Alekseev, that is, in The Church Dictionary two graphic fixation traditions are synthetized - cyrillic and laic, which helped to represent religious content.

Key words: church dictionary, Pyotr Alekseev, religious lexicon, Russian lexicography, orthography history, Orthodoxy, $18^{\text {th }}$ century, religious style.

Citation. Feliksov S.V. On Graphicfeatures in Spelling Codification of Religious Lexicon in the Church Dictionary by P.A. Alekseev. Vestnik Volgogradskogo gosudarstvennogo universiteta. Seriya 2, Yazykoznanie [Science Journal of Volgograd State University. Linguistics], 2017, vol. 16, no. 4, pp. 89-99. (in Russian). DOI: https://doi.org/10.15688/jvolsu2.2017.4.7
\end{abstract}

\section{ОСОБЕННОСТИ ГРАФИКО-ОРФОГРАФИЧЕСКОЙ КОДИФИКАЦИИ РЕЛИГИОЗНОЙ ЛЕКСИКИ В «ЦЕРКОВНОМ СЛОВАРЕ» П.А. АЛЕКСЕЕВА}

\section{Сергей Владимирович Феликсов}

Православный Свято-Тихоновский гуманитарный университет, г. Москва, Россия

\footnotetext{
Аннотация. Исследование находится в русле проблем формирования и динамики орфографических норм русского языка, в частности проблем кодификации и стабилизации правописания слов, относящихся к конфессионально-терминологической системе православного вероучения, и становления орфографических норм религиозного стиля.

В статье представлены результаты лингвотекстологического анализа двух изданий «Церковного словаря» протоиерея П.А. Алексеева (1773-1779 и 1794 гг.) - первого в истории русской лексикографии сочинения, в котором наиболее полно фиксируются и толкуются лексемы церковной сферы употребления. Выявлена специфика реализации в «Церковном словаре» принципов орфографической кодификации религиозной лексики: морфологического, традиционного, фонетического; показана преемственная связь
} 
словаря с предшествующими лексикографическими и грамматическими трудами разных авторов. Установлены и классифицированы случаи вариантных написаний в соответствии с их типами: 1) графикоорфографическим, включающим графемные и фонетико-морфологические варианты, 2) морфологическим, включающим собственно морфологические и морфолого-фонематические варианты, и 3) этимолого-словообразовательным. Охарактеризованы причины, обусловившие возникновение вариантных написаний, отраженных в словаре. Показано, что «Церковный словарь» П.А. Алексеева является синтезом двух письменных графических традиций (кириллицы и гражданицы), который осуществлен с целью выражения религиозного содержания.

Ключевые слова: церковный словарь, Петр Алексеев, религиозная лексика, русская лексикография, история орфографии, Православие, XVIII век, религиозный стиль.

Цитирование. Феликсов С. В. Особенности графико-орфографической кодификации религиозной лексики в «Церковном словаре» П.А. Алексеева // Вестник Волгоградского государственного университета. Серия 2, Языкознание. - 2017. - Т. 16, № 4. - C. 89-99. - DOI: https://doi.org/10.15688/jvolsu2.2017.4.7

\section{Введение}

XVIII век характеризуется его современниками как время «великого несогласия» в области русского правописания [Св ьтовъ, 1787, с. 7]. Исследования по истории языка подтверждают то, что многие печатные тексты этого столетия содержали «самый широкий и пестрый диапазон колебаний» в области орфографии [Биржакова, Войнова, Кутина, 1972, с. 183]. Однако именно в этот период «происходит процесс постепенного создания теории правописания и правил орфографии» [Григорьева, 2004, с. 33], а также формирование «русского научно-богословского языка» [Флоровский, 1991, с. 113].

В свете сказанного особый интерес представляет изучение особенностей графико-орфографической кодификации в текстах XVIII в. важнейшего в культурном отношении и наиболее устойчивого в плане своего языкового оформления пласта слов, обозначающих понятия религиозной сферы. Первым масштабным опытом орфографической кодификации конфессиональной лексики в истории русской письменности стал изданный в 1773-1794 гг. «Церковный словарь» протоиерея П.А. Алексеева ${ }^{1}$. В этом лексикографическом труде впервые была собрана воедино и описана значительная часть орфографических форм религиозной лексики, употреблявшейся в церковных текстах. Он незаслуженно обойден вниманием исследователей, хотя является важным источником изучения истории становления норм правописания русского литературного языка.

\section{Издания «Церковного словаря» \\ П.А. Алексеева в свете} графико-орфографической проблематики

Публикация «Церковного словаря» П.А. Алексеева была одобрена Святейшим Правительствующим Синодом, а также митрополитом московским Платоном (Левшиным), однако, несмотря на положительное цензурное решение со стороны церковных властей, издания Словаря были осуществлены в светских типографиях: первое издание (17731779 гг.) - в типографии Московского университета, а второе (1794 г.) - в типографии Академии наук в Санкт-Петербурге.

Данное обстоятельство, безусловно, нарушавшее устоявшуюся традицию, связанную с книгопечатанием церковных книг, объясняется, по-видимому, тем, что ко второй половине XVIII в. культурный конфликт, проявлявшийся в оппозиции церковнославянского и русского языков, ощущается общественным языковым сознанием не так остро, как это было в начале века, а образовавшееся ко времени издания Словаря «гражданское наречие» получает «отсутствовавший у него прежде престиж» [Живов, 2017, с. 1087], постепенно «захватывая» область богословской литературы, и начинает в целом претендовать на роль «универсального языка культуры» [Живов, 2017, с. 954]. Помимо этого, безусловно, на окончательноерешение относительно типографии, в которой должен быть издан «Церковный словарь», непосредственное влияние оказал и статус самого П.А. Алексеева, занимавшего к тому времени должность профессора Московского университета, а также являвшегося членом Академии Российской. 
Выбор светской типографии обусловил использование при печати «Церковного словаря» гражданской азбуки (в последней к моменту выхода труда П.А. Алексеева ее редакции, которую она получила в 1758 г. решением Академии наук). Указанное обстоятельство, а также тот факт, что Словарь был создан как толковательное руководство для изучения славянской Библии и церковных книг, не могли не повлечь за собой совмещения в его тексте элементов графической системы гражданицы и кириллицы, порождая различного рода семиотические противоречия. При кодификации религиозной лексики П.А. Алексеев, с одной стороны, опирался на авторитет церковных книг, с целью узнавания читателем фиксируя слово в той графико-орфографической форме, в которой оно было употреблено в толкуемом тексте, а с другой стороны, учитывал графико-орфографические нормы, свойственные гражданским текстам второй половины XVIII в., где лексикографируемая единица также могла активно употребляться и иметь отличное от церковнославянского источника написание.

Прямым доказательством подобного рода семиотической гибридности в «Церковном словаре» служит как употребление «литер» гражданской печати, в том числе используемого для издания текстов светского содержания диграфа io, так и наличие в тексте Словаря графических элементов, используемых при печати церковнославянских текстов: надстрочных знаков (титла, сопровождающего написание наиболее употребительной в церковных книгах лексики, внесенной в Словарь; «острого» и «тупого» ударения), отмененных Петром I букв греческого происхождения и «і» с тремой в издании Словаря 1794 г.

\section{Типы вариантных написаний} религиозной лексики в «Церковном словаре» П.А. Алексеева

Сказанное выше, а также факт отсутствия в XVIII в. единых правил в области русского письма, несмотря на предпринимаемые в то время попытки создания теории русского правописания и кодификации орфографической нормы в грамматиках отечественных ученых, обусловили наличие в рассматриваемых из- даниях «Церковного словаря» П.А. Алексеева вариантных написаний.

С целью выявления характерных особенностей графико-орфографической кодификации религиозной лексики, нашедших отражение в «Церковном словаре», представим результаты лингвотекстологического анализа рассматриваемых изданий, классифицировав различные случаи вариантных написаний в соответствии со следующими их типами: графико-орфографическим, морфологическим и этимолого-словообразовательным.

1. Графико-орфографический тип вариантных написаний религиозной лексики.

Графико-орфографический тип нашел выражение в «Церковном словаре» в виде вариантных написаний графемного и фонетико-фонологического характера.

1.1. Вариантные написания графемного характера. Как известно, одной из причин вариативности в русской письменности XVIII в. является неупорядоченность, связанная с употреблением дублетных графем [Каверина, 2010, с. 37]. В «Церковном словаре» нашли отражение следующие типы графемного варьирования, коснувшиеся омофоничных букв как гласных, так и согласных.

Графемные варианты слов с различи$\boldsymbol{e м}$ букв $\boldsymbol{i}-\boldsymbol{u}$. Буква $i$ в соответствии с требованиями грамматик XVII-XVIII вв. регулярно употребляется в Словаре только в позиции перед буквой, обозначающей сочетание гласного с [j] на конце слова (догматизированіе, литургисаніе), в остальных случаях наблюдается вариативность. В первом издании Словаря $i$, как правило, пишется в начале заимствованных слов: іерей (греч. ієрєи́), ірмосъ

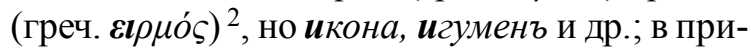
ставке $<$ pri $>$ в позиции перед буквами гласных: богопріимецъ, пріяти душу ${ }^{3}$, в приставке $<$ arhi $>$ вне зависимости от позиции: apxieпископъ, архістратигъ, а также в корне заимствованных слов на месте греческой

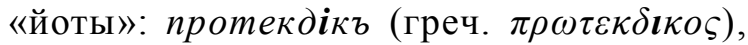

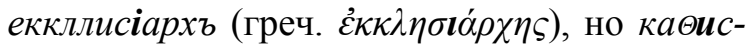
мa, рипида и др., что в целом согласуется с орфографической установкой грамматических сочинений Ф. Поликарпова, Ф. Максимова, описывающих церковнославянскую норму. Во втором издании Словаря данная норма сохраняется, однако в некоторых случаях наблю- 
дается тенденция к написанию буквы $u$ вне зависимости от фонетического окружения звука, ею обозначенного, в написании же приставки $<a r h i>i$ сохраняется только перед буквами гласных: богоприимецъ, архистратигъ, протекдикъ, паннихида и др.

Таким образом, наблюдения над употреблением в тексте Словаря букв $i-u$ в словах религиозной семантики свидетельствуют не только о колебаниях в их написании, но и о замене близкой к латинской манере начертания буквы $i$ буквой $u$ в соответствии с общей орфографической тенденцией второй половины XVIII в. Такая орфографическая установка автора «Церковного словаря» была противоположна взглядам В.Е. Адодурова, В.Н. Татищева, В.К. Тредиаковского, ратовавших за выведение из употребления буквы $u$, в то же время полностью согласовалась с мнением М.В. Ломоносова, А.А. Барсова, Н.Г. Курганова, считавших, что буква $i$ не является функционально значимой для русской графической системы.

Графемные варианты слов с различи$\boldsymbol{e м}$ букв $\boldsymbol{r}-\boldsymbol{u}$. Буква $\boldsymbol{r}$, восстановленная в гражданском алфавите Академией наук в 1758 г., в соответствии с традицией последовательно употребляется в первом издании «Церковного словаря» в заимствованных словах религиозной семантики в позиции начала слова, а также между буквами согласных на месте греческой буквы «ипсилон», обозначая звук [и]: паннихіда (греч. $\pi \alpha v v v \chi i \delta \alpha)$, протопресвьтерь (греч. $\pi \rho \dot{\tau} \tau о \varsigma$ и $\pi \rho \varepsilon \sigma \beta \dot{v} \tau \varepsilon \rho о \varsigma)$, เпакой (греч. v́л-

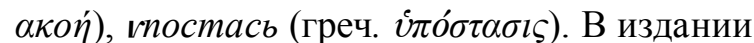
Словаря 1794 г. в написании некоторых наиболее употребительных слов намечается характерная для того времени тенденция к графической русификации - замене $\boldsymbol{r}$ на $u$ (паннихида, протопресвитеръ).

Графемные варианты слов с различи$\boldsymbol{e м}$ букв $\boldsymbol{b}-\boldsymbol{e}$. Как свидетельствуют грамматические руководства В.Е. Адодурова, М.В. Ломоносова, А.А. Барсова и др., на протяжении XVIII в. буквы $\mathbf{k}$ и $e$ сохраняют свое различие в звуковом значении в книжном произношении, однако на практике, в частности в рассматриваемых нами изданиях «Церковного словаря», данные графемы в ряде случаев являются взаимозаменяемыми (к прр қяновщина купреяновщина, цъдило - иедило). Такое по- ложение дел обусловлено отсутствием в грамматиках, предшествующих изданию Словаря П.А. Алексеева, строгих правил, касающихся употребления данных букв. В то же время, несмотря на этот факт, а также на отсутствие сформированных так называемых «ятевых списков», буква $\boldsymbol{t}$ стабильно употребляется Алексеевым в словах с корнями $\sigma \mathbf{k} c-$, в $\mathbf{b} d$-, в $\mathbf{k} p-, 2 н \mathbf{k} 6-, c в \mathbf{k} m-, c \mathbf{k} d-, m \mathbf{k} u-$, uв $\mathbf{k} m-$, u и др., служащих для образования слов рели-

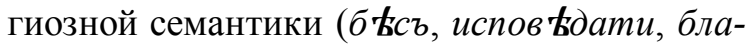

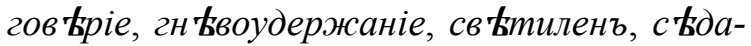
лень, ут ншитель, ив ктоносная нед ияломудренно).

Графемные варианты слов с различи$\boldsymbol{e}$ м букв 3 - $\boldsymbol{s}$. Буква $s$ употребляется в издании «Церковного словаря» 1794 г. в ограниченном количестве лексических единиц, в частности в написании корней слов $\boldsymbol{s} 6 \mathbf{k} 3 \partial a, \boldsymbol{s} 6 \mathbf{k} p b$, sльй, sмiŭ. В остальных случаях во всех рассматриваемых изданиях Словаря при кодификации религиозной лексики употребляется буква з (заамвонная молитва, законъ в tры). Сравнивая рассматриваемые издания Словаря на предмет написания букв з и $s$, необходимо отметить, что в издании 1773 г. в указанных выше словах в соответствии с общей тенденцией того времени вместо $s$ писалась буква 3, но, начиная с издания 1776 г., видимо, под латинофильским влиянием происходит переориентация в их написании: з последовательно заменяется на $s$. В целом же, вопреки усилиям В.Е. Адодурова, В.Н. Татищева, В.К. Тредиаковского, пытавшихся ввести в активное употребление букву $s$, в орфографии «Церковного словаря» эта графема нечастотна.

Графемные варианты слов с различием буквенных написаний $r-\varepsilon, \Theta-\phi$, $\psi-$ $\boldsymbol{n c}, \boldsymbol{z}-\boldsymbol{\kappa} \boldsymbol{c}$. В первом издании «Церковного словаря» при кодификации слов религиозной семантики иноязычного происхождения вместо $r, \Theta, \downarrow$, з в написании многих слов данной группы используются буквы $8, \phi$, а также сочетания букв $n c$ и $\kappa c$. Во втором издании Словаря в отдельных случаях наблюдается тенденция к реставрации написаний, включающих указанные греческие буквы, однако в целом колебания, касающиеся употребления данных букв, не устраняются, показателем чего служат случаи вариантной орфографической кодификации религиозной лексики, отражающие 
процесс графической русификации заимство-

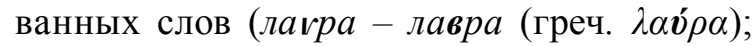
аөонь - афонъ (греч. "АӨ

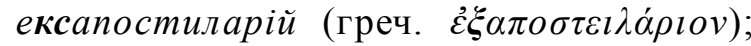

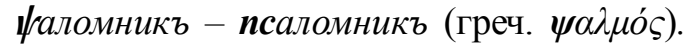

Таким образом, отмеченные в «Церковном словаре» графемные колебания при кодификации религиозной лексики, с одной стороны, свидетельствуют об опоре Алексеева на эллинофильскую (а не латинофильскую) графическую традицию, а с другой стороны, отражают процесс графической русификации, связанный с освобождением текстов, изданных в светских типографиях, от дублетных, в частности «клерикальных букв» ${ }^{4}$.

\section{2. Вариантные написания фонети-} ко-фонологического характера. Указанный тип вариантных написаний религиозной лексики, нашедших отражение в «Церковном словаре», затрагивает как согласные, так и гласные фонемы в иноязычных и славянских словах, отражая различные процессы в русском языке второй половины XVIII в.

А) Обратим внимание на группу вариантных написаний, встречающихся в «Церковном словаре», вызванных различной традицией чтения греческих текстов, сложившейся в рамках рейхлинового и эразмового типов произношения. Этой причиной объясняется наличие в Словаре вариантов кодификации греческих слов с различением буквенных обозначений: $\boldsymbol{r}-e, e-u, \varepsilon-\sigma, \Theta-m, m-\partial$ : гnархъ -

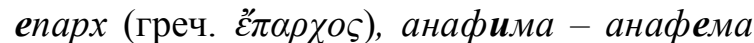
(греч. $\dot{\alpha} v \alpha \dot{\theta} \theta \varepsilon \mu \alpha$, от $\dot{\alpha} v \alpha \tau i \theta \eta \mu l)$, боносіане - воносіане (греч. ßо́vобоธ), каөедральный -

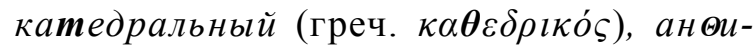

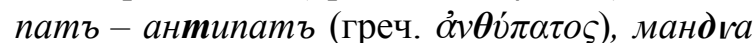
архіерейская - мантіа архіерейская) (греч. $\mu \alpha v \delta \dot{v} \alpha \varsigma)$, где первый вариант отражает освященную религиозной практикой рейхлиновскую норму чтения, а второй - эразмову, обусловленную западным влиянием.

Б) Другая группа вариантных написаний иноязычной религиозной лексики, зафиксированной в «Церковном словаре», обусловлена:

различием огласовки слова (греческой «сигмы») в греческом и латинском языках, приводящим к различению буквенных написаний согласных $c-3:$ екклесіасть-екклеsia (греч. $\varepsilon \kappa \kappa \lambda \eta \sigma l \alpha \sigma \tau \dot{\zeta} \varsigma, \dot{\varepsilon} \kappa \kappa \lambda \eta \sigma i \alpha$ - лат. ecclesiastes, ecclesia); схисматики - схизма-

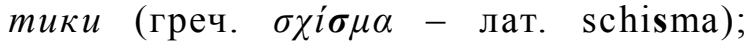
протопресвгтер в - протопрезвгтеръ

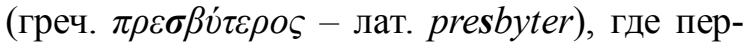
вый вариант отражает греческую, а второй латинскую нормы чтения;

различными вариантами произношения слова в рамках одного языка: лукіферіане луціферіане (лат. luciferiani), кирка - кирхе (нем. kirche).

Указанные две группы вариантных написаний охватывают незначительную часть религиозной лексики, содержащейся в «Церковном словаре». Основная часть религиозных слов в рассматриваемых нами изданиях Словаря последовательно оформляется П.А. Алексеевым в соответствии с принятой к тому времени традицией церковного чтения:

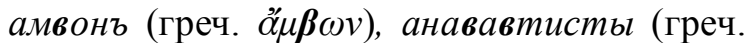

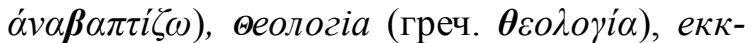

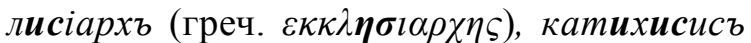

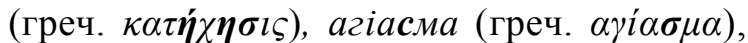
$к а \Theta и с м а$ (греч. ка́ $\theta \imath \sigma \mu \alpha)$ и др. Однако важно отметить, что во втором издании труда Алексеева, несмотря на общую пуристическую установку его автора, в некоторых случаях находит отражение норма эразмова и латинского типов произношения, которая широко распространилась в России в XVIII в. в противопоставление церковной традиции: гортеане

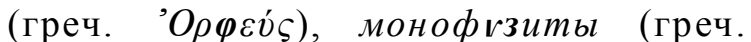

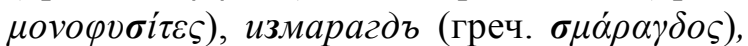

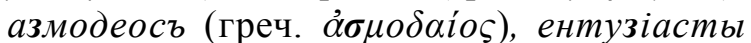
(греч. $\varepsilon v \theta o v \sigma l \alpha \sigma \mu o ́ \varsigma)$ и др. Помимо этого, в Словаре зафиксированы единичные случаи так называемых слов-гибридов: вамбак (греч. $\boldsymbol{\beta} \alpha \mu \boldsymbol{\beta} \alpha \dot{\kappa} \iota$ ov).

В) Широкое распространение находят в «Церковном словаре» вариантные написания, связанные с процессом фонологической адаптации заимствованной религиозной лексики: вариантные написания с различением корневых гласных и согласных, обусловленные наличием разных орфографических форм в языке-источнике: велзевуль (греч. $\beta \boldsymbol{\alpha} \alpha \lambda \zeta \varepsilon \beta$ -

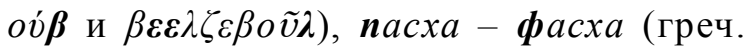
$\boldsymbol{\pi} \alpha \dot{\sigma} \chi \alpha$ и $\boldsymbol{\alpha} \sigma \chi \alpha)$, фелон - фенолій (греч. $\varphi \varepsilon \lambda \dot{v} v \uparrow$ и $\varphi \alpha \iota v o ́ \lambda \eta \varsigma) ;$

вариантные написания с меной корневых гласных и согласных, обусловленные различием фонемного облика слова в языке-источнике и языке-посреднике: купреяновщина - 


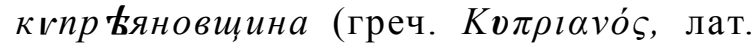
Сурrianus), ромская - римская церковь

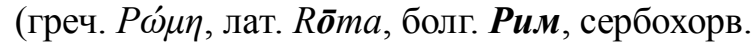
$P \hat{u} M)$;

вариантные написания с различением корневых гласных и согласных, вызванные влиянием «народного» произношения: $\boldsymbol{a}$ mарь - олтарь (лат. altāre) ${ }^{5}$, епитиміа -

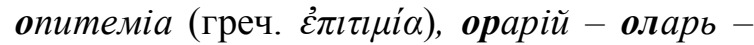
уларій (греч. ф́ро́рıоv), паннихида - панафида (греч. $\pi \alpha v v v \chi i \delta \alpha)$, кардиналь - гординаль (лат. cardinālis ${ }^{6}$ );

вариантные написания слов с одинарными / удвоенными буквами, вызванные упрощением двойных согласных: сакосъ-саккосъ

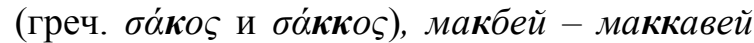
(греч. $\mu \alpha \kappa \alpha \beta \alpha \tilde{\text { Iо } ~ и ~ и ~} \mu \alpha \kappa \kappa \alpha \beta \alpha \tilde{\imath o l})$.

Приведенные примеры показывают, что орфографические колебания являются следствием действия различных фонетических (диссимиляция, ассимиляция, выпадение звуков, метатеза) и лексико-семантических процессов.

Г) Помимо указанных случаев, в «Церковном словаре» наблюдаются вариантные написания религиозных слов славянского происхождения. В частности, в Словаре широко представлены вариантные написания, связанные с обозначением на письме мягкости [л], [p], [н], [т], [д]: епископи селстіи - епископы сельстіи, олгино крещеніе - ольгино крешеніе, пастырство - пастырьство, домашняя иерковь - домашняя иерьковь, кознствуюшій - козньствуюшій, пятдесятнииа - пятьдесятникъ, господствіе - господьствуемый. В связи с этим необходимо отметить, что написание «фонетического $b$ » в середине слова не было четко регламентировано в грамматиках того времени и предполагало «принципиальную вариативность» [Каверина, 2010, с. 237]. В Словаре также зафиксированы слова славянского происхождения, возникновение вариантных написаний в которых обусловлено конкуренцией старославянских и древнерусских форм: юродство уродство, свтща - св тиа.

Проанализировав основные вариантные написания фонетико-фонологического характера, встречающиеся в «Церковном словаре» при кодификации религиозной лексики, можно отметить, что их наличие обуслов- лено, с одной стороны, различными культурными противоречиями, характерными для XVIII в., которые нашли отражение на семиотическом уровне в виде конкурирующих тенденциозных орфографических форм, а с другой стороны, недостаточной упорядоченностью правил передачи звукового облика слова графическими средствами русского языка.

2. Морфологический (формальнограмматический) тип вариантных написании религиозной лексики.

Процесс формирования нового секулярного языка в XVIII в. обусловливает поиск и новой морфологической нормы, находя широкое отражение в текстах того времени в виде появления вариантных грамматических форм [Живов, 2017, с. 975]. Морфологические варианты в «Церковном словаре» представлены как у заимствованных, так и славянских по происхождению религиозных слов. Их наличие объясняется, прежде всего, смешением и аналогическим воздействием унаследованных от старого строя языка парадигматических различий.

\section{1. Собственно морфологические варианты.}

Варианты, связанные с различием заимствованных существительных в грамматическом роде возникают в процессе приспосабливания заимствованных слов к русской морфологической системе путем мены флексий $(e / я)$ : богословіе (ср. р.) - богословія (ж. р.) (греч. $\theta \varepsilon o \lambda o \gamma i \alpha, \dot{\eta})$, а также в результате упрощения основы заимствованного слова: рипидіонъ

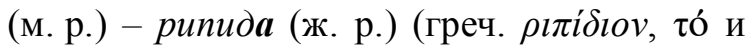

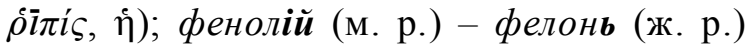

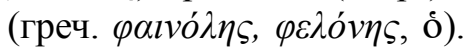

\section{2. Морфолого-фонематические ва-} рианты.

А) Варианты падежных окончаний, обусловленные конкуренцией церковнославянских и русских морфологических форм:

имен прилагательных в им. п. ед. ч. м. р. с твердой и мягкой основами: ветхой зав $\mathbf{k} m ъ-$ ветхій зав tътъ; в им. п. мн. ч. ж. р.: иарскія двери - иарскіе двери;

имен существительных в п. П. мн. ч.: $O$

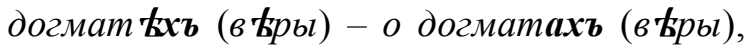
о обряд tкx (иерковныхъ) - обрядахъ (иерковныхъ). 
Основным написанием при кодификации являются формы с флексиями -iŭ, -ie (у прилагательных) и -ахъ (у существительных).

Б. Вариантные написания финалей, заимствованных из греческого существительных и субстантивированных прилагательных женского рода (на - $\alpha$ и - $\eta$ ) іа - ія: литургіа - ли-

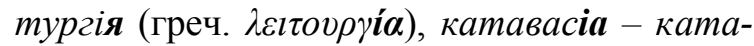

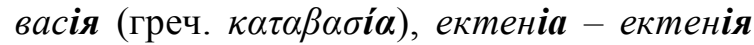

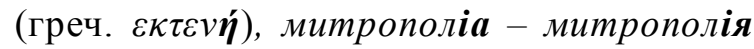

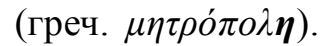

В. Варианты форм инфинитива с конкуренцией церковнославянской и русской форм на -ть / -ти (животворить - животвори$\boldsymbol{m u}$, вождел $\mathbf{k m b}-$ вождел $\mathbf{k m u ) . ~ О т м е т и м , ~}$ что во втором издании «Церковного словаря» наблюдается тенденция замены инфинитива с суффиксом -ть на форму с суффиксом -ти. При этом ведущей формой при кодификации глагольной религиозной лексики в рассматриваемых изданиях Словаря является форма с суффиксом -ти (молебствовати, монашествовати и мн. др.).

Морфологический тип вариантных написаний отражен в ограниченном круге грамматических форм, при этом важно отметить, что П.А. Алексеев при кодификации религиозной лексики в большинстве случаев (кроме указанных глагольных форм) ориентировался на морфологическую норму, сложившуюся в «гражданском наречии».

3. Этимолого-словообразовательный тип вариантных написаний религиозной лексики.

В «Церковном словаре» нашел отражение процесс появления словообразовательных дублетов как у славянских, так и заимствованных слов, обозначающих религиозные понятия, который был обусловлен формированием моделей русской словообразовательной системы в XVIII веке. В связи с этим в написании слов в Словаре встречаются следующие варианты этимолого-словообразовательного типа.

А) Варианты форм заимствованных существительных им.п. ед.ч., имеющих в финальной части сочетание (суффикс) -ий и упрощенную форму, заканчивающуюся на согласный, а также конкурирующие формы с суффиксами -ий/-ион- (-іоп-): антимисій антиминсъ (греч. $\dot{v} v \imath$ и лат. mensa, греч. $\left.\dot{\alpha}^{\nu} \tau \tau \mu \eta \dot{v \sigma} \sigma o v\right)$, орарій - оларь (греч.

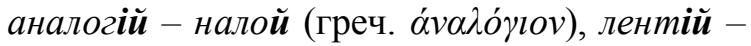
лентіонъ (греч. $\lambda \varepsilon ́ v \tau \imath o v)$.

Б) Варианты форм существительных им.П. мн.ч. заимствованных слов: пакліане

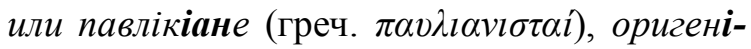
$\boldsymbol{a н} b l$ - оригеніи (греч. $\dot{\omega} \rho \imath \varepsilon v l \alpha v o i)$, монта-

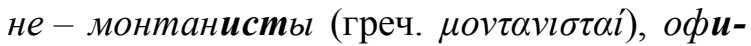
mbl - офіане (греч. ӧ $ө \tau \alpha l)$, адамиты адаміане (греч. $\dot{\alpha} \delta \alpha \mu \tilde{\imath} \tau \alpha l, \dot{\alpha} \delta \alpha \mu l \alpha v o i)$, авелониты - авеліане (греч. $\alpha \beta \varepsilon \lambda l \alpha v \eta \dot{)}$ ), копты -

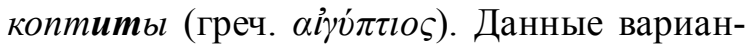
ты широко отражены в Словаре при фиксации слов, обозначающих сторонников еретических учений. Как видно, эти формы отражают процесс освоения русским языком словообразовательной структуры слов с распространенными в XVIII в. суффиксами иноязычного происхождения: -иан-, -ист-, -ит-.

В) Варианты, связанные с чередованием «гласный [e], [o] / ноль звука» в корне, обусловленные конкуренцией русских и церковнославянских форм слов: доблественныц й доблственный, ложииа - лжиия.

Г) Варианты, обусловленные появлением славянских однокорневых разносуффиксальных параллельных образований с суффиксами -ник-/-еи-, Ø/-еи-, -ниц-/-ии-, -ник/-щик- и их конкуренцией: шестодневникъ шестодневецъ, вредословъ - вредословець, нарукавницы - нараквицы, чаломникъ - псаломщикъ.

Приведенные выше примеры, иллюстрируя процесс этимолого-словообразовательной адаптации, свидетельствуют, не только о существовании во второй половине XVIII в. альтернативных словообразовательных моделей при образовании религиозной лексики, которые отражают тенденцию, связанную с переоформлением средствами русского языка иноязычных новаций, но и констатируют факт конкуренции церковнославянских и русских словообразовательных форм.

Таким образом, оказавшись в ситуации противоборства различных культурных и орфографических начал, автор «Церковного словаря», как это было показано выше, не пошел по пути «умолчания» или предельного сокращения вариантных написаний слов, а избрал путь осмысления живых явлений, происходящих в то время в русском правописании. 


\section{Орфографические принципы кодификации религиозной лексики в «Церковном словаре» П.А. Алексеева и его нормативные источники}

Основными словарными источниками при кодификации религиозной лексики стали для П.А. Алексеева: азбуковники; «Лєе̌иконъ, славєноршсскїй» Памвы Берынды (1653); «Лєёїконъ трехзычный» Федора Поликарпова (1704). Помимо этого, Алексеев черпал лексический материал для словника из различных по тематическому и жанровому характеру текстовых источников: изданий допетровской и послепетровской эпохи (в том числе Библии, 1751 г.), творений святых отцов Церкви, богослужебных книг, церковноправовых и исторических сочинений.

Поскольку лексикографическая деятельность П.А. Алексеева, приходившаяся на вторую половину XVIII в., совпала со временем «теоретических поисков наиболее рациональных принципов правописания» [Панов, 1965, с. 15], многие не только текстовые, но и лексикографические источники, послужившие для составителя «Церковного словаря» нормативными пособиями, обнаруживают разнобой в написании лексем с религиозной семантикой (см. таблицу). Что касается текстовых источников, то орфографическая норма в них была еще более подвижна и отражала многочисленные колебания в написании слов [Пекарскій, 1862, с. 2].

Данное положение дел потребовало от автора «Церковного словаря» формирования четкой позиции, связанной с вопросом об определении орфографических принципов кодификации словарного материала. Несмотря на включение в «Церковный словарь» вариативных написаний, оформление большей части религиозных слов подчинено морфологическому и традиционному принципам.

В соответствии с морфологическим принципом в «Церковном словаре оформляются:

корни слов, содержащие проверяемые

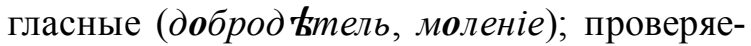
мые звонкие и глухие согласные (архистратигъ, архимандрить); непроизносимые согласные (благов ъстники, распустная книга); и после приставок (безъиначественный, отъити ко отиземъ);

приставки, заканчивающиеся на согласный: без-, воз-, от-, раз-, чрез- и др. (безблагодатный, безсребреникъ, возблагодать, возспасаемый, отданиіе праздника, разкольничествовати, раздорникъ, чрезcoборіе);

суффиксы -ств-, -ец-- и др. (игуменство, владыколюбецъ);

окончания существительного в тв.п. ед.ч. (ангеломъ, монахомъ) и др.

Традиционному принципу в «Церковном словаре» подчинено написание непроверяемого безударного гласного (догматикъ, литургія); буквы 2 на месте звука [в] в окончаниях -ого, -его р.п. имен прилагательных (божественнаго, небеснаго); буквы ч, обозначающей [ш] в сочетании чн (обручникъ, л вствичникъ);

\section{Примеры орфографической вариантности кодификации религиозной лексики} в лексикографических произведениях XVI-XVIII вв.

\begin{tabular}{|c|c|c|c|}
\hline «Азбуковник»* & $\begin{array}{c}\text { «Ає̌̈̈конz» } \\
\text { П. Берынды }\end{array}$ & $\begin{array}{c}\text { «Хє厃̌̈конz» } \\
\text { Ф. Поликарпова }\end{array}$ & $\begin{array}{c}\text { «Церковный словарь» } \\
\text { П.А. Алексеева }\end{array}$ \\
\hline архисинагогъ & apXicínaror’ & apXIcínarór’h & архісгнагогъ, архисмнагогъ \\
\hline анаөема & ANA-OUMA ANA-ӨEMA & ANAREEMA & анаөема, анаєима \\
\hline ектенія & EKTENIA & - & ектенія, ектеніа \\
\hline enapxz & 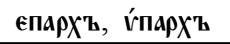 & 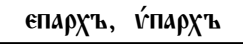 & enapx, snapxz \\
\hline катапетазма & КАТАПЕТ АСМА & - & катапетасма \\
\hline лентіе & NENTION' & МЕNTǏ & лентій, лентіонъ \\
\hline презвитерь & ПГЕСВÍ ТЕ९' & ПГесви́'ТЕ९Ъ & пресвитеръ, протопрезвитеръ \\
\hline
\end{tabular}

Примечание. * - в работе было использовано подготовленное И.П. Сахаровым издание «Азбуковника», основу которого составили два списка «Велико-Русскихъ Словарей»: 1) «Сказаніе неудобь познаваемымъ ръчемъ, иже обрьтаются во святыхъ книгахъ Русскаго языка <...>» (XVI век) и 2) «Книга, глаголемая Алфавитъ, содержащая въ себъ толкованіе иностранныхъ ръчей, иже обретаются во святыхъ книгахъ не преложены на Русскій языкъ» (XVII век). Подробно см.: [Азбуковникъ, 1849]. 
букв $u, e$ после букв ж, $и$ (жизнодатель, жертвенник, шестопсалміе, шестодневъ); двойных согласных в корнях заимствованных слов (паннихида, приммикгрій).

Помимо этого, важно отметить, что в тексте «Церковного словаря» проявляется устойчивая тенденция к следованию

фонетическому принципу при написании буквы $a$ в безударной приставке рас- (pacпустная книга); буквы bl после $u$ во флексиях (мгроносицы, подиерковнииы);

лексико-семантическому принципу при написании приставок пре- и при- (премудрость, премірень, приобщитися, приходити ко Христу); корней слов мир- ('спокойствие') с буквой $u$ и мір- ('вселенная') с буквой $i$ (миръ вамъ, міродержецъ); собственных имен с прописной буквы (Адамъ, Иерусалимъ);

лексико-грамматическому и словообразовательно-грамматическому принципам при написании н и нн в суффиксах разных частей речи (духонасыщенный, жертвенникъ, десятинная изерковь, канонникъ).

Названные выше принципы правописания в тексте «Церковного словаря» не реализуются в полной мере, что во многом и обусловливает наличие вариантных написаний религиозной лексики. Однако важно отметить, что в анализируемых изданиях Словаря написания слов, отступающие от упомянутых выше принципов, фиксируются в пределах заголовочной части, как правило, после основного варианта или сопровождаются соответствующим нормативными указаниями, а также стилистическими разграничениями (например: Богословіе, не право же пищущіе изображають Богословія; Ряса, или исправн ъе съ гр. Раса; Кірка, а исправн ъе кірхе; Еөимонь, правильн ъе же Меєимонь; езапостіларій, или по нын ъинему правоп.: ексапостиларій; Паннихида, просто Панафида).

В реализации обозначенных в этом разделе орфографических принципов написания слов религиозной семантики в «Церковном словаре» большую роль сыграли указанные выше предшествующие ему лексикографические труды. Помимо них, П.А. Алексеев не мог не учитывать нормативные указания и теоретические разработки, касающиеся ведущих орфографических принципов русского письма, изложенные, прежде всего, в грамматических руководствах М. Смотрицкого, М.В. Ломоносова, В.П. Светова, А.А. Барсова.

\section{Заключение}

«Церковный словарь» стал первым в истории русской культуры лексикографическим сочинением религиозного содержания, изданным в светской типографии, явив собой, по терминологии В.М. Живова, «текст гибридного регистра» [Живов, 2017, с. 948]. Реконструируя графическую систему «Церковного словаря», можно отметить, что она есть не что иное, как промежуточный вариант алфавита, совмещающего графические символы кириллицы и гражданицы, представляющий в истории русского письма один из первых опытов синтеза двух письменных графических традиций, осуществляемый с целью выражения религиозного содержания.

Выдержавший несколько переизданий и приобретший широкое распространение в научных кругах «Церковный словарь» сыграл важнейшую роль в деле кодификации и стабилизации правописания значительного пласта лексики, относящейся к конфессиональнотерминологической системе православного вероучения, а также в целом в формировании орфографических норм религиозного стиля, вследствие чего стал одним из основных нормативных пособий для составителей «Словаря Академіи Россійской».

Все выше сказанное позволяет считать «Церковный словарь» П.А. Алексеева ценным источником изучения истории правописания религиозной лексики, функционирующей в русском языке.

\section{ПРИМЕЧАНИЯ}

${ }^{1}$ В работе к исследованию привлечены издания «Церковного словаря», вышедшие при жизни автора первое издание: «Церковный словарь» (1773 г.), «Дополненіе къ Церковному словарю» (1776 г.), «Продолженіе Церковнаго словаря» (1779 г.); второеиздание: «Церковный словары» (1794 г.). Подробно о «Церковном словаре» П.А. Алексеева см. [Феликсов, 2009].

2 Здесь и далее этимологические сведения приводятся с использованием словарных материалов, представленных на портале «Этимология и 
история слов русского языка» ИРЯ РАН (http:// etymolog.ruslang.ru/).

${ }^{3} \mathrm{~B}$ грамматике М. Смотрицкого $i$ в данной приставке предписывается употреблять в любом фонетическом положении. Подробно о норме употребления рассматриваемых графем в грамматиках XVII-XVIII вв. см.: [Каверина, 2010].

4 Этим же процессом обусловлено отсутствие в тексте «Церковного словаря» в написании слов букв «омега» и «ук», несмотря на то, что «в практике письма» данные графемы использовались до конца XVIII в. [Каверина, 2010, с. 81].

${ }^{5}$ Данные орфографические варианты возникают вследствие влияния окающей нормы, характерной для высокого стиля второй половины XVIII в.

${ }^{6}$ Слово заимствовано через немецкий (kardinal) или непосредственно из французского (cardinal). По мнению В.Г. Демьянова, написание с 2 возникло в результате лексико-семантической аналогии, в частности, ассоциации со словом гордый: гординал - «тот, который гордый, занимающий высший духовный сан» [Демьянов, 1990, c. 107].

\section{СПИСОК ЛИТЕРАТУРЫ}

Биржакова Е. Э., Войнова Л. А., Кутина Л. Л., 1972. Очерки по исторической лексикологии русского языка XVIII века: Языковые контакты и заимствования. Л. : Наука. Ленингр. отд-ние. $431 \mathrm{c}$.

Григорьева Т. М., 2004. Три века русской орфографии (XVIII-XX вв.). М. : Элпис. 455 с.

Демьянов В. Г., 1990. Фонетико-морфологическая адаптация иноязычной лексики в русском языке XVII века. М. : Наука. 157 с.

Живов В. М., 2017. История языка русской письменности. М. : Ун-т Дмитрия Пожарского. Т. 2. $1285 \mathrm{c}$.

Каверина В. В., 2010. Становление русской орфографии в XVII-XIX вв.: правописный узус и кодификация : дис. ... д-ра. филол. наук. М. 436 с.

Панов М. В., 1965. Принципы русской графики и орфографии // Обзор предложений по усовершенствованию русской орфографии (XVIII-XX вв.) / отв. ред. В. В. Виноградов. М. : Наука. 500 с.

Пекарскій П. П., 1862. Наука и литература въ Россіи при Петрь Великомъ. СПб. : Издание Товарищества «Общественная польза». Т. 1. 596 с.

Свътовъ В. П., 1787. Опытъ новаго россійскаго правописанія. СПб. : При Имп. Акад. Наук. 36 с.

Феликсов С. В., 2009. «Церковный словарь» протоиерея Петра Алексеева // Русская речь. № 3. C. 80-87.
Флоровский Г., 1991. Пути русского богословия. Вильнюс : Вильнюс. правосл. епарх. упр. 599 с.

\section{ИСТОЧНИКИ}

Азбуковникъ, 1849. Изд. : Сахаровъ, И. П. Сказанія русскаго народа. СПб : Тип. Сахарова, Т. 2. Кн. 5. С. 135-191.

Алексьевъ П. А., 1773. Церковный словарь. М. : Печ. при Имп. Моск. ун-те. 396 с.

Алексњевъ П. А., 1776. Дополненіе къ Церковному словарю. М. : Печ. при Имп. Моск. ун-те. $324 \mathrm{c}$.

Алексњевъ П. А., 1779. Продолженіе Церковнаго словаря. М. : Тип. Имп. Моск. ун-та. 299 с.

Алексъевъ П. А., 1794. Церковный словарь : в 3 т. СПб. : Печ. При Имп. Акад. Наук. Т. 1.359 с.; T. 2, 412 c.; T. 3, 304 c.

Берында П., 1653. Лєе̌̆иконъ, славєноршсскій. Кутеин : Тип. Богоявленская. 328 с.

Поликарповъ Ф., 1704. Лєе̌иконъ трехзычный. М. : Синодальная тип. 403 с.

\section{REFERENCES}

Birzhakova E.E., Voynova L.A., Kutina L.L., 1972. Sketches on historical lexicology of Russian of the 18 ${ }^{\text {th }}$ century: Language contacts and loans. Leningrad, Nauka Publ. 431 p. (in Russian).

Grigoryeva T.M., 2004. Three centuries of the Russian spelling (the $18^{\text {th }}-20^{\text {th }}$ centuries). Moscow, Elpis Publ., 2004. 216 p. (in Russian).

Demyanov V.G., 1990. Phonetic-morphological adaptation of foreign-language lexicon in Russian of the $17^{\text {th }}$ century. Moscow, Nauka Publ. 157 p. (in Russian).

Zhivov V.M., 2017. History of language of the Russian writing. Moscow, Universitet Dmitriya Pozharskogo Publ., vol. 2. 1285 p. (in Russian).

Kaverina V.V., 2010. Formation of the Russian spelling in the $17^{\text {th }}-19^{\text {th }}$ centuries: spelling usage and codification. Dr. philol. sci. diss. Moscow. 436 p. (in Russian).

Panov M.V., 1965. Principles of Russian graphics and spelling. Review of offers on improvement of the Russian spelling (the $18^{\text {th }}-20^{\text {th }}$ centuries). Moscow, Nauka Publ. 500 p. (in Russian).

Pekarskiy P.P., 1862. Science and literature in Russia under Peter the Great. Saint Petersburg, Izdanie Tovarishchestva "Obshchestvennaya polza", 1862, vol. 1.596 p. (in Russian).

Svetov V.P., 1787. Experience of new Russian spelling. Saint Petersburg, Pri Imp. Akad. nauk Publ. 36 p. (in Russian). 
Feliksov S.V., 2009. The Church dictionary of the archpriest Petr Alekseev. Russkaya rech, no. 3, pp. 80-87. (in Russian).

Florovskiy G., 1991. Ways of the Russian divinity. Vilnius, Vilnius. pravosl. eparh. upr. Publ. 599 p. (in Russian).

\section{SOURCES}

Azbukovnik, 1849. Sakharov I.P. Skazaniya russkago naroda [Legends of the Russian people]. Saint Petersburg, Tip. Sakharova, vol. 2, book 5, pp. 135-191.

Alekseev P.A., 1773. Tserkovnyy slovar [Church dictionary]. Moscow, Pech. pri Imp. Mosk. unte. $396 \mathrm{p}$.
Alekseev P.A., 1776. Dopolnenie k Tserkovnomu slovaryu [Addition to the Church dictionary]. Moscow, Pech. pri Imp. Mosk. un-te. 324 p.

Alekseev P.A., 1779. Prodolzhenie Tserkovnago slovarya [Continuation of the Church dictionary]. Moscow, Tip. Imp. Mosk. un-ta. 299 p.

Alekseev P.A., 1794. Tserkovnyy slovar: $v 3 t$. [Church dictionary. In 3 vols.]. Saint Petersburg, Pri Imp. Akad. nauk Publ., vol. 1. 359 p.; vol. 2. 412 p.; vol. 3. $304 \mathrm{p}$.

Berynda P., 1653. Leksikon slavenorosskiy [Slavic Russian Lexicon]. Kutein, Tip. Bogoyavlenskaya, $328 \mathrm{p}$.

Polikarpov F., 1704. Leksikon treazychny [ThreeLanguage Lexicon]. Moscow, Sinodalnaya tip. $403 \mathrm{p}$.

\section{Information about the Author}

Sergey V. Feliksov, Candidate of Sciences (Philology), Associate Professor, Department of Pedagogics and Methodology of Primary Education, Saint Tikhon's Orthodox University, Novokuznetskaya St., 23-5A, 115184 Moscow, Russia, svfeliksov@gmail.com, https://orcid.org/0000-0002-5928-3311

\section{Информация об авторе}

Сергей Владимирович Феликсов, кандидат филологических наук, доцент кафедры педагогики и методики начального образования, Православный Свято-Тихоновский гуманитарный университет, ул. Новокузнецкая, 23, стр. 5а, 115184 г. Москва, Россия, svfeliksov@gmail.com, https:// orcid.org/0000-0002-5928-3311 